\title{
Global climate change or national climate changes? An analysis of the performance of online issue publics in integrating global issues
}

\author{
Ueli Reber \\ Institute of Communication and Media Studies, University of Bern, Bern, Switzerland
}

\section{Correspondence details}

E-mail: ueli.reber@ikmb.unibe.ch

Phone: +41316313874

Universität Bern

Institut für Kommunikations und Medienwissenschaft

Fabrikstrasse 8

CH-3012 Bern

\begin{abstract}
This paper analyzes how the complex global spatiality of climate change is integrated into online national public discourses. Although the Web is an important venue for public discourses, little is known about its capability to integrate transnational issues. By looking at two types of communicative links (hyperlinks and referential links), we assess the degree and the scope of transnational integration for the four cases of Germany, Switzerland, the United Kingdom, and the United States. The findings show that these national discourses are heavily transnationalized. However, the scope of transnationalization is restricted to countries of the Global North, with a clear focus on the United States. This leads to the conclusion that the Web's capability to integrate transnational issues is limited.
\end{abstract}

Keywords: climate change; public discourse; online; Web; transnationalization; comparative research; hyperlinks; referential links; automated content analysis

\section{Funding}

This publication was created in the context of the Research Unit "Political Communication in the Online World" (FOR 1381), Subproject 07, which is funded by the German Research Foundation (DFG, project number 155794648). The subproject is also funded by the Swiss National Science Foundation (SNSF, project number 100017E-154100). 


\section{Introduction}

Climate change is experienced and caused locally, but the climate system is global (IPCC, 2014). This is why many of those most affected by the changing climate have contributed the least to the greenhouse gases causing the problem (IPCC, 2014). Because of this complexity, climate politics are local, national, regional, and global. In other words, political arenas on different levels are closely intertwined in a multilevel system of climate governance (Di Gregorio et al., 2019; Jänicke, 2017; Simonis, 2017). However, the national arena plays a particularly important role in this system, as national governments are responsible for both negotiating and implementing international treaties, such as the Paris Agreement (2015). Since national governments are legitimized by the citizens of their country (i.e., the national public), it is crucial that there are national public discourses on climate change legislation, domestic greenhouse gas emissions, and the local impacts of the changing climate. But it is just as crucial that there is a transnational public discourse on international conferences and treaties, legislation in foreign countries, and the effects of climate change in other parts of the world. After all, climate change is a global problem that requires global awareness and a coordinated effort to solve it. From this point of view, a public discourse in which both national and transnational facets of the issue are simultaneously presented, linked and discussed — that is integrated — is not only desirable, but necessary.

But how well does this integration of both national and transnational aspects into the public discourse on climate change work? Does the complexity of the issue translate into a public discourse that is national, global, or integrated? Looking at public discourses in legacy media, most previous studies found what is best described as transnationalized national discourses, meaning that public discourses are first and foremost national because of national 
media systems but are transnationalized through the frequent reporting about what is happening in other countries and on the international level (Olausson, 2009; Schäfer, Post, Schwab \& Kleinen-von Königslöw, 2018; Wessler, Wozniak, Hofer \& Lück, 2016). It is no surprise that the United Nations Framework Convention on Climate Change (UNFCCC) conferences are major catalysts for the transnationalization of national discourses (Eide \& Kunelius, 2010). However, it is not only international politics that trigger transnationalization but also exceptional events (e.g., storms, droughts, rallies, elections) and prominent actors (e.g., politicians, celebrities) in other countries (Schäfer et al., 2018).

This, however, does not necessarily hold true for the public discourse on the Web. Bennett, Lang and Segerberg (2015) found highly fragmented national discourses when they analyzed the online debate on climate change in Germany and the United Kingdom based on (trans)national hyperlink networks. The authors found that national and transnational actors constitute separate publics around the climate issue, each with a specific political arena in focus (i.e., a country or a transnational body like the European Union). Because these issue publics are only weakly connected, the domestic discourses remain mostly domestic.

By increasing the "spatial scope" (Koopmans \& Erbe, 2004, p. 107) of the national discourses, legacy media thus seem to integrate the complex spatiality of the climate change issue better than the seemingly borderless Web. In this study, we examine whether there is empirical evidence to support this statement by analyzing and comparing the integrative performance of the national discourses about climate change on the Web in Germany, Switzerland, the United Kingdom, and the Unites Sates. To do so, we use the actor-centered issue mapping approach (Marres, 2015). This approach allows us to determine both degree and scope of transnational integration of the issue networks that represent these countries' online public sphere devoted to climate change (Marres \& Rogers, 2005). Specifically, we 
address two research questions:

- To what degree are the climate change issue networks in Germany, Switzerland, the United Kingdom, and the United States transnationalized?

- What is the scope of transnationalization of these countries' climate change issue networks?

Studying and comparing four cases allows us to identify both common and countryspecific patterns of transnationalization (Esser \& Hanitzsch, 2012). In fact, such a comparative design is the only way to study the geography of the public discourse on climate change beyond the "bounded 'container[s]' of the Westphalian nation state" (Volkmer, 2019, p. 251), without ignoring them as the main political arenas in climate governance. As a result, this study contributes to a better understanding of the public discourse on climate change at both the national and transnational level.

Moreover, our analysis is not only based on hyperlinks - the skeleton of issue networks - but also considers referential links. Referential links are references to objects, persons, places, etc. made in the text of a web page. Just like hyperlinks, they represent communicative flows and therefore have a spatial dimension (Koopmans \& Zimmermann, 2010). Although the analysis of referential links is standard when studying the transnationality of discourses in legacy media, they are mostly ignored in Web studies. Especially studies that use the issue mapping approach usually focus on hyperlinks. However, it is unclear whether and how hyperlinks and referential links differ when it comes to transnational communicative flows. We address this gap by examining both types of links side by side. By doing so, we contribute to the extension of the empirical scope of controversy analysis in online settings (cf. Marres, 2015). 


\section{Theoretical Considerations}

\section{Issue Networks}

The Web is an exceptional platform for public discourse, as there are no technical barriers that would restrict public discourses to a certain space. With a simple website, everyone with internet access can get involved in any public discourse anywhere in the world at any time. This makes the Web the cornerstone of the networked public sphere-a decentralized public sphere that is facilitated by digital communication technologies (Benkler, 2006; Friedland \& Rojas, 2006). It builds on multi-directional communicative links among a potentially infinite number of actors. This notion fits the architecture of the Web perfectly, as the Web not only allows actors to easily become their own publishers but also to connect with others via hyperlinks (Park, 2003).

Hyperlinks are the essential structural element of the Web. It directly depends on them, whether webpages are visible to the audience (i.e., the users) or not (González-Bailón, 2009). This is either because users move from one webpage to another via hyperlinks or because the algorithms of search engines, such as Google (Brin \& Page, 1998), deduce the importance of a webpage from the hyperlinks it receives (Koopmans \& Zimmermann, 2010). Search engines thereby take advantage of the fact that actors with similar interests connect in issue networks (Marres \& Rogers, 2005).

Issue networks are networks of public communication that form around a common and often contested topic (issue). The network consists of webpages and the hyperlinks connecting them. However, issues do not exist a priori but are created through the different views expressed by the actors in the network (Marres, 2006). The issue, therefore, constitutes the network, and the network, conversely, constitutes the issue. Because issue networks are open to connection and contestation among all interested actors (including citizens), the networks 
can be understood as full-fledged issue publics (Bennett et al., 2015).

Issue networks are thus forums in which public discourses take place (e.g. on climate change). Because they typically consist of actors from different fields (e.g., politics, civil society, science, economy), they are not only a site of contention but also of public opinion formation (Marres, 2006). Because of their unrestricted accessibility, issue networks have the potential to serve as a public source of knowledge and inspiration, as originator of public criticism and support for political actions, as well as indicators of cultural and political change. These processes are not limited to the issue network. In the network public sphere, the views and opinions formed in issue networks may spill over into mass media and politics and thus become eventually socially and politically effective (Pfetsch, Adam \& Bennett, 2013). In order to gain a more comprehensive understanding of social and political developments, it is therefore essential to study the public communication of issue networks.

\section{Degree and Scope of Transnationality}

Issue networks are not geography-free but tied to a political space. Otherwise, they could hardly become politically efficient (Fraser, 2007). The spatiality of issue publics is created through the association of its actors with a particular political space. Actors can communicate their scope - that is their sphere of reference - via their website, for example by choosing a country-specific domain ending (e.g., ".us" or ".de”). A national issue network therefore emerges when actors from the same country connect. By focusing on domestic affairs and actors, such networks produce an issue that is primarily relevant to a national public. We can thus speak of a national issue public. By integrating foreign actors (i.e., by linking to them), the network becomes transnationalized. This extends the scope of the issue network, as it now also includes the views of foreign actors. What is debated in the network thus becomes meaningful for a transnational public, which is why we can speak of a 
transnational issue public in this case.

However, to what degree an issue public is transnationalized is relative. Based on the notion of Karl Deutsch (1953), the degree of transnationalization is typically defined as the ratio of communicative interactions within a country to communicative interactions beyond the country (Gerhards \& Rössel, 1999; Koopmans \& Erbe, 2004). When applied to issue networks, this means that the degree of transnationalization is determined by the ratio of hyperlinks between actors with the same scope (i.e., "their" country) to hyperlinks between actors with different scopes.

Due to the important role of the national arena in climate politics (Simonis, 2017), it is reasonable to proceed from national issue publics also when studying discourses on the technically boundless Web (Cammaerts \& Van Audenhove, 2005; Segerberg, 2012). The starting points in this study are therefore national issue networks. In a first step, the networks thus consist of domestic actors (i.e., actors from the same country), but are then "open to connection and contestation" (Bennett et al., 2015, p. 112) among actors from every other political sphere. This allows us to check whether the spatial reach and the boundaries of public communication correspond with national borders or go beyond them (the degree of transnationalization). It also allows us to identify exactly which other spheres are integrated into the national publics (the scope of transnationalization).

\section{Communicative Links: Hyperlinks and Referential Links}

Analyzing hyperlinks is a popular approach among scholars who are interested in the transnationality of the Web. Many studies on international hyperlink networks (Barnett, Chung \& Park, 2011; Barnett \& Park, 2005; Halvais, 2000; Janc, 2015; Park, Barnett \& Chung, 2011) and "international news flows" (Chang, Himelboim \& Dong, 2009; Himelboim, 2010; Segev, 2010; Segev \& Hills, 2014) have measured cross-border communication based 
on hyperlinks. Studies with a more specific focus on the transnationality of issue publics have likewise focused on hyperlinks in order to measure the issue networks' transnationality (Bennett et al., 2015; Hepp et al., 2016; Koopmans \& Zimmermann, 2010; Rogers \& BenDavid, 2008; Shumate \& Dewitt, 2008).

However, hyperlinks are only one specific form of communicative link. Another, much more common form are links established through references in the text. That is by mentioning an object, a person, or any other entity that could be named in the text of a webpage (i.e., without setting a hyperlink). We call these in-text mentions referential links.

Although hyperlinks are the main structural element of the Web and the skeleton of issue networks, referential links should not be ignored when analyzing public discourses online. Mainly because not all places and actors can be addressed via hyperlinks (e.g., countries, groups of people), and hyperlinks are sometimes avoided (e.g., to avoid that a contradicting view becomes visible). Although the analysis of referential links is not unusual in legacy media research (e.g., Adam, 2007; Wessler, Peters, Brüggemann, Kleinen-von Königslöw \& Sifft, 2008; Koopmans \& Statham, 2010; Schäfer et al., 2018), it has rarely been used to analyze communication on the Web. Exceptions are Koopmans and Zimmermann (2010), who manually coded statements from actors ("claims") on webpages and Segev (2010), as well as Segev and Hills (2014), who automatically extracted country names from online news sites to measure transnationality in public communication online.

Referential links and hyperlinks are thus two kinds of the same phenomenon: communicative links. In order to obtain the full picture, both types should be analyzed simultaneously. This is why we assess and compare degree and scope of transnationalization for both hyperlinks and referential links. 


\section{Data and Methods}

\section{Case Selection}

We concentrate on the national discourses in Germany, Switzerland, the United Kingdom (UK), and the United States (US). Although these are all Western democracies and signees of the UNFCCC (1992), the situation for the actors involved in climate politics are different. While Germany, Switzerland and the UK are making some political efforts to meet the reduction targets defined in the Paris Agreement, this is not the case for the US (Burck, Hagen, Marten, Höhne \& Bals, 2019; Iacobuta, Dubash, Upadhyaya, Deribe \& Höhne, 2018). Climate change is an issue that deeply divides the American society (Dunlap, McCright \& Yarosh, 2016), but less so European societies (McCright, Dunlap \& Marquart-Pyatt, 2015). Moreover, the US is considerably larger than the other three countries and therefore fields far more scientists, policy makers, and other actors with an interest in climate change. Compared to the other countries, the US is also home to more (hyper-partisan) online media and blogs that produce Web content for a domestic public (Heft, Mayerhöffer, Reinhardt \& Knüpfer, 2019). Consequently, the possibilities for political influence and alliances are different in the US and European countries. This is likely to affect the communication behavior of the actors constituting the domestic issue networks (Häussler et al., 2017). Apart from that, the UK1 and Germany are members of the European Union, where climate change is a major policy field (Jordan, van Asselt, Berkhout, Huitema \& Rayner, 2012), while Switzerland and the US are not. British and German actors must therefore take a additional political sphere into account, when they decide on their communication strategy. However, the European sphere also offers them additional opportunities to publicly promote their interests (Bennett et al., 2015). Finally, the national languages differ: German is spoken in Germany and Switzerland (in

1 At the time of data collection. 
some parts), English in the UK and US. Compared to the "English" Web, the "German" Web is small, which means that the German-speaking actors have few possibilities to link to actors of the same language. The following analysis aims to show whether these contextual factors affect the linking behavior of the actors in the climate change issue networks of these countries.

\section{Generating Issue Networks}

The four country-specific issue networks were gathered using a hyperlink-tracing procedure, which consisted of four main steps (Adam, Häussler, Schmid-Petri \& Reber, 2016). First, we identified the most prominent actors in each country based on literature reviews, expert validation, 2 and country-specific Google searches.3 Prominent actors are known, credible and visible on the Web. The Google searches were used to determine the visibility of the actors. The literature reviews and the expert interviews then helped to determine whether an actor is known and credible. We chose actors who scored well in all three criteria. In this step, the focus was exclusively on national challenger actors. Following Kriesi (2004, p. 189), we understood challengers to be those actors with a (political) goal but no institutionalized access to formal political institutions or the media (e.g., non-governmental organizations, bloggers, universities, think tanks). They are the "champions of online climate communication" (Schäfer, 2012, p. 530), as they make extensive use of the Web to address the public (or parts of the public). However, their motivations and interests in public communication can differ greatly (cf. Stein, 2009). Therefore, also their national respectively

2 We asked researchers investigating climate change discourse and policy in the four countries to validate and, if necessary, modify the lists of actors obtained by literature reviews and Google searches.

3 The English terms "climate change" and "global warming," as well as the corresponding German terms "Klimawandel" and "Globale Erwärmung," were used as search terms. These are often used and identified as appropriate search terms to capture the issue of climate change (Painter \& Gavin, 2016; Shapiro \& Park, 2015). 
transnational orientation potentially differs. In order to capture the whole spectrum of the debate, the four most prominent climate advocates, as well as the four most prominent climate skeptics, were chosen as starting points for the snowball sampling procedure (see list of actors in Appendix A).

This second step was done with the help of the crawler software Issue Crawler (Rogers, 2013). We set the crawler to start from the main page dealing with climate change on the seed actors' websites (the URLs are also listed in Appendix A), following all internal hyperlinks two levels deep into the respective website, and then collected all outgoing hyperlinks from these pages that were directed to external webpages, no matter whether they were challenger actors or not. The obtained issue networks are therefore not just challenger networks. In a final iteration, the crawler checked for hyperlinks running between the already indexed pages. Pretests have shown that more iterations primarily lead to the inclusion of US actors. The national networks of the European countries thus become quasi US networks. Moreover, an additional iteration produced a large number of webpages unrelated to climate change. Due to capacity constraints, it was not possible to identify, download and check all these webpages on a monthly basis. Therefore, no further crawling iterations were made.

In the third step, we downloaded all crawled webpages and then automatically indexed them according to our search terms in order to ensure that the climate change issue was actually addressed on these webpages. This is the crucial step in generating issue networks on the basis of hyperlink networks, as it removes a substantial amount of noise (Waldherr, Maier, Miltner \& Günther, 2017).

Finally, we aggregated the crawled webpages and manually coded them. The aggregation was done at the actor level. This means that webpages were not only aggregated on the basis of their domain but that domains of the same actors were also grouped together. 
Actors could be both individuals (e.g., bloggers) and organizations (e.g., NGOs, companies, governmental bodies). Then, the scope of all actors was manually coded using the information usually found on the "About us" page or a similar section of their website(s). The guiding principle was to take the perspectives of the actors and to determine whether they have a national focus (e.g., Switzerland, Germany) or a transnational one (e.g., EU, United Nations).4 We have taken into account whether an actor is the national branch of a transnational organization. For example, we coded the national scope for Greenpeace Germany and the transnational scope for Greenpeace international.

Hyperlinks originating from foreign actors were eventually removed from the networks, as the focus of the study is on national issue publics. This is the strictest and most conservative definition of national issue publics, as only the linking behavior of the domestic actors is taken into account. This ensures that the country-specific degree and scope of transnationalization is captured, without any bias caused by the linking of foreign actors who are only indirectly involved (i.e., by being linked into the network) in the national climate change discourse.

Instead of using only one issue network per country, we used 12 (or 11)5 and reported mean values for all measures. For each country, one issue network was generated at the beginning of each month between June 2012 and May 2013. This was done because issue networks typically have a relatively stable core, but always show a certain fluctuation at the 4 The coding was done by two trained student assistants. The training process consisted of several rounds of coding an identical set of actors, followed by a comparison with the master coding and a discussion of the results. The intercoder reliability was assessed by comparing the coders' classification with the master coding. We used Krippendorff's alpha to measure the agreement between the coders' classification and the master coding as the coefficient is comparable across any number of coders, values, metrics, and sample sizes. For the scope variable (distinguishing 199 categories), Krippendorff's alpha was 0.93 and therefore satisfactory (1 means complete agreement). Throughout data collection, critical cases were discussed and coded in coders' meetings. 5 A total of 12 for Switzerland and the UK and, due to technical issues in the network gathering process, 11 for Germany and the US. 
margins. A comparison of snapshots taken at only one point in time can therefore lead to biased findings. To obtain more reliable measurements, we decided to smoothen the networks over a 12-month period. Table 1 shows the average number of actors, hyperlinks, and referential links of the issue networks. It also illustrates the variance at the fringes of the networks by reporting the standard deviations.

\begin{tabular}{llcccc}
\hline & & Germany & Switzerland & United Kingdom & United States \\
\hline \multirow{3}{*}{ Actors } & Domestic & $88(10)$ & $24(3)$ & $127(7)$ & $441(71)$ \\
& Foreign & $190(23)$ & $120(8)$ & $218(16)$ & $341(62)$ \\
& Unknown & $5(1)$ & $4(1)$ & $14(2)$ & $47(8)$ \\
\hline \multirow{3}{*}{ Hyperlinks } & Domestic & $2,808(668)$ & $180(94)$ & $1,071(157)$ & $20,511(3,348)$ \\
& Transnational & $5,800(747)$ & $387(279)$ & $2,518(532)$ & $14,234(2,042)$ \\
& Unknown & $6(3)$ & $4(4)$ & $156(9)$ & $1,121(370)$ \\
\hline \multirow{3}{*}{ Referential links } & Domestic & $5,830(464)$ & $127(30)$ & $11,785(1,424)$ & $48,277(6,509)$ \\
& Transnational & $5,342(375)$ & $472(198)$ & $16,308(2,679)$ & $35,932(4,676)$ \\
& Unknown & $2,762(286)$ & $206(94)$ & $13,810(1,289)$ & $28,923(4,024)$ \\
\hline Number of networks & & 11 & 12 & 12 & 11 \\
\hline
\end{tabular}

Table 1. Key figures of issue networks, including number of actors, number of hyperlinks, and number of referential links (rounded means, standard deviations in parentheses).

\section{Extracting Referential Links}

To identify the referential links in the text of the webpages, automated and manual content analysis methods were used. First, 10,095 actors were identified as important for the climate change discourses in Germany, Switzerland, the UK, and the US. This was done by the manual content analysis of 1,680 webpages, 1,545 newspaper articles, and 774 political documents dealing with climate change. The news articles and political documents were published by newspapers and political institutions located in the four countries and obtained through media database searches and web scraping governmental websites (cf. Häussler, Schmid-Petri, Adam, Reber \& Arlt, 2016).6 They were collected at the same time as the issue networks, and the manual coded webpages were directly sampled from the issue networks'

6 The same search terms as for the webpages were used to index the newspaper articles and political documents. 
corpus. Trained coders identified the most important actors in every document and coded their scope if it was indicated in the text.7

The manual coded list of climate actors was merged with a generic list of around 1.3 million names of people and organizations (e.g., "Angela Merkel”) as well as multiword units (e.g., "market economy"). We then used this extensive list as a dictionary to search for named entities in the text of the webpages. In addition, we trained two probabilistic sequence classifiers - one for German- and one for English-language documents—and used them for the identification of additional, previously unknown named entities. Conditional random field models (CRF) from the Stanford CoreNLP package (Finkel, Grenage \& Manning, 2005) were used as classifier algorithms. Of the additionally identified named entities, the 500 most frequent were then coded by a trained coder.

Whether the reference to a named entity counted as a national, transnational, or unknown referential link was inferred from both the scope of the webpage and the scope of the named entity (e.g. the mention of Angela Merkel on a webpage of Greenpeace Germany would thus count as a domestic referential link, the mention of Barack Obama on the same webpage would count as transnational link). As for the hyperlinks, only referential links from domestic actors' webpages were collected. The obtained numbers are summarized in Table 1. What is obvious, compared to hyperlinks, is the higher number of unknown referential links. This is due to the often unspecific references. For example, actors often referred to "scientists" or "science" in general rather than a person or an institution specifically. In such cases, the scope of the named entity was labelled as unknown.

\footnotetext{
7 The coding was done by seven trained coders. As for the networks, the intercoder reliability was assessed by comparing the coders' classification with a master coding. For the scope variable (distinguishing 199 categories), Krippendorff's alpha was 0.82 and thus acceptable.
} 


\section{Measures}

To measure the degree of transnationalization, we used the E-I index (Krackhardt \& Stern, 1988). The index is a metric for what Koopmans and Erbe (2004) called "the relative density of public communication within and between political spaces" (p. 102). For the case of the national issue network $i$, the index is calculated as follows:

$$
E I_{i}=\frac{t_{i}-d_{i}}{t_{i}+d_{i}}
$$

where $d_{i}$ denotes the number of domestic links and $t_{i}$ the number of transnational links in the national issue network $i$. An E-I score of +1 would, therefore, indicate that every link is transnational. A score of -1 would indicate the opposite, that every link is domestic. An E-I score of 0 means that there are the same number of domestic and transnational links in the network. For the degrees reported in the following section, we first calculated the E-I ratios for all the issue networks gathered and then computed the mean ratio per country on this basis.

To measure the scope of transnationalization, we differentiated between horizontal and vertical transnational links (Koopmans \& Erbe, 2004). Horizontal-transnational links connect actors/entities from different countries. This means that the primary scope of both source and target is national (but different). This is the case when a German think tank (e.g., Heinrich Boell Stiftung) links to a British NGO (e.g., Oxfam UK). A vertical-transnational link connects an actor with a primarily national scope with an actor/entity with a scope that is transnational. This could be, for example, the European Commission, representatives of the UN, or a globally active NGO (e.g., Greenpeace). The distinction between horizontal and vertical links is useful because it provides us with an indication of the importance of international/supranational institutions in climate politics relative to national ones. The scope of transnationalization of the issue networks was thus determined by the relative frequency of 
(1) domestic, (2) horizontal-transnational (differentiating between countries), (3) verticaltransnational, and (4) unknown links. The values presented in the following section are based on the mean number of links over all the issue networks per country.

\section{Findings}

\section{Degree of Transnationalization}

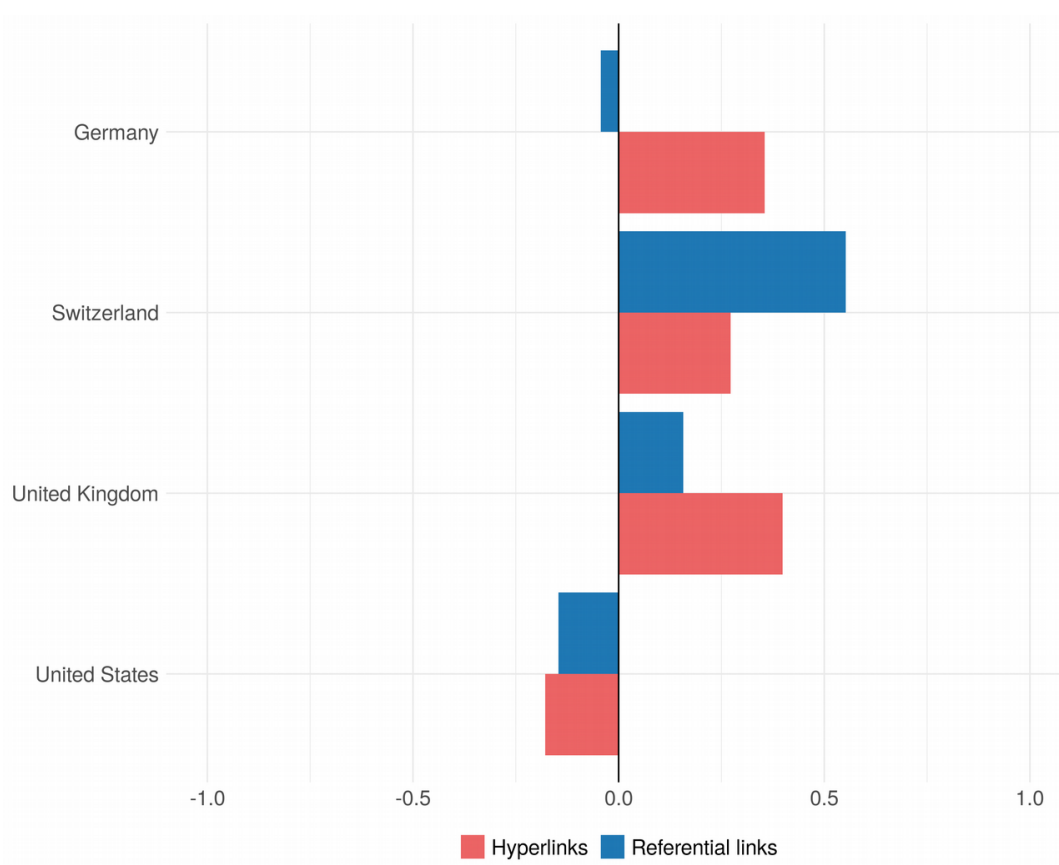

Figure 1. Degrees of transnationalization (E-I index) across countries and type of communicative links.

The different degrees of transnationalization are shown in Figure 1. Looking at the hyperlinks first, Figure 1 shows that there is a positive degree in all countries except the US. This means that the relative density of transnational hyperlinks in Germany $(\mathrm{EIH,DE}=0.355)$, Switzerland $(\mathrm{EIH,CH}=0.272)$, and the UK $(\mathrm{EIH,UK}=0.399)$ is higher than that of domestic links. In the US, however, the domestic hyperlinks are denser than the transnational ones $(\mathrm{EIH,US}=-0.179)$.

The picture is slightly different for referential links. In particular, German domestic actors have a faint preference to link domestically when they use referential links $\left(E I_{R, D E}=-\right.$ 
0.043). This is in contrast to hyperlinks, where the German actors have a clear transnational orientation. In the other countries, the E-I index for referential links goes in the same direction as for hyperlinks. In Switzerland, there is an even clearer external orientation $(\mathrm{EIR,CH}=$ $0.552)$, whereas the UK $(\mathrm{EIR}, \mathrm{UK}=0.157)$ and the US $(\mathrm{EIR,US}=-0.146)$ are a little closer to the center in this case.

Overall, these results show that there is a pronounced, if varied, external orientation in all the European countries, with Switzerland being the most externally oriented. The US, on the other hand, shows a slight domestic, or internal, orientation.

\section{Scope of Transnationalization}

Figure 2 summarizes where the communicative links of the actors in the issue networks go. Looking at the transnational hyperlinks first, the figure shows that German actors link mainly to actors in the US (36.7\%). A smaller fraction of the hyperlinks lead to actors from the UK (13\%) and actors with a genuine transnational scope (12.7\%). Only 2.9\% of the hyperlinks in the German issue network point to Swiss actors, and even less $(2.1 \%)$ to actors from other countries (i.e., Canada $0.5 \%$, Ireland $0.5 \%$, Liechtenstein $0.5 \%$ ).

The Swiss actors, in turn, link preferably to Germany (26.1\%). Less frequently, the hyperlinks of Swiss actors lead to websites from transnational actors (23.7\%) and American webpages $(16.5 \%)$. Only on very rare occasions $(2.1 \%)$ does a link from a Swiss actor lead to another country (Denmark $0.2 \%$, Austria $0.2 \%$, Russia $0.2 \%$ ).

British actors most frequently link horizontally to American actors (29.4\%) and less often vertically to transnational actors $(15.4 \%)$. The other transnational hyperlinks lead to actors from the Commonwealth (Canada 10.6\%, Australia 5.1\%, New Zealand 2.6\%, India $0.2 \%)$, as well as Norway (3.1\%). Other countries include France $(0.5 \%)$ and Germany $(0.1 \%)$ 


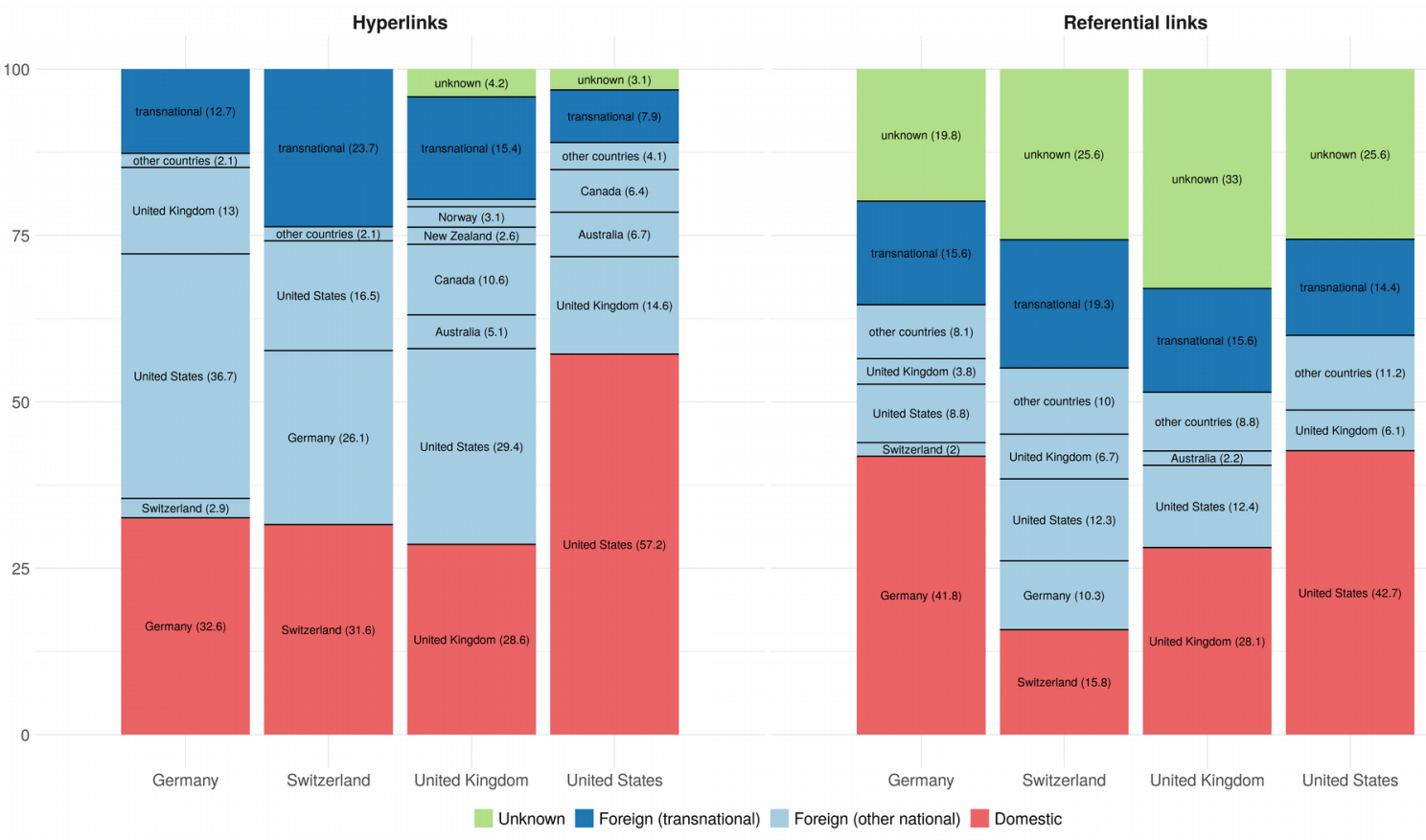

Figure 2. Scope of hyperlinks and referential links across countries (relative frequency, percentages in parentheses). The category "other countries" summarizes countries with a share of less than 2 percent.

Actors from the US link to British actors most frequently (14.6\%) and less often to actors at the transnational level (7.9\%), from Australia (6.7\%), or Canada (6.4\%). Hyperlinks to other countries (Germany 1.4\%, New Zealand 1.2\%, Czech Republic 0.9\%, Denmark $0.2 \%$, Sweden $0.2 \%$ ) account for only $4.1 \%$ of the hyperlinks in the American issue networks. The picture is only slightly different for referential links. First, there are more links to the transnational level (vertical transnationalization). Second, the scope for horizontal transnationalization is a little wider with referential links than with hyperlinks. German actors link to the transnational level the most (15.6\%). Horizontally, they mainly link to actors from the US (8.8\%), the UK (3.8\%), and Switzerland (2\%), followed by Brazil (1.5\%), France $(1.1 \%)$, China $(0.6 \%)$, and Russia (0.5\%). The horizon of Swiss actors mainly encompass the transnational level (19.3\%). Horizontally, Swiss actors most often link to the US (12.3\%), Germany (10.3\%), and the UK (6.7\%). Other countries include China (1.4\%), Pakistan (1.1\%), and Afghanistan (0.8\%). On British webpages, users most likely find references to the transnational level $(15.6 \%)$ or to actors from the US (12.4\%). Less frequently, they find 
references to named entities based in Australia (2.2\%), Canada (1.2\%), Germany (0.9\%), China (0.7\%), Denmark (0.5\%), France (0.5\%), India (0.4\%), Russia (0.4\%), and Switzerland $(0.4 \%)$. Finally, American actors refer most frequently to actors with a transnational scope $(14 \%)$. Horizontally, they frequently refer to actors from the UK (6.1\%). Other countries include Australia (1.2\%), China (1.1\%), Canada (1\%), and Germany (0.8\%).

\section{Discussion}

In this study, we evaluated the degree and the scope of transnationalization in the online discussion of climate change in four countries. The goal was to determine whether the discourse is nationally fragmented or transnationally integrated. Based on the findings reported in the previous section, we can say that the online discourses on climate change in Germany, Switzerland, the UK are transnationally integrated. In the US, the picture differs: despite a notable degree of transnationalization, there is a clear internal orientation in the US discourse. As in legacy media (Schäfer et al., 2018), horizontal transnationalization is more pronounced than vertical transnationalization in all countries. Thus, not only are supranational institutions and transnational civil society actors integrated into the national issue publics but also foreign national actors. This shows that even actors whose primary focus is on the domestic national sphere consider climate change a transnational issue. Consequently, transnational links appear to be a central tool in their online communication toolbox. They can be used to support foreign allies, to legitimize the own position, to educate the audience, or to mobilize the public (cf. Schäfer, 2012). Horizontal links allow the actors to refer to peers and political institutions on the national level, while vertical links highlight the specialized civil society actors and institutions at the international and supranational level (Bennett et al., 2015). However, the high number of horizontal links can be indicative that, despite the prominent international and supranational institutions dealing with climate change (e.g., EU, 
$\mathrm{UN}, \mathrm{IPCC})$, the national level is still the most important in climate politics. Whether this is actually the case, a more in-depth analysis of the strategies and motivations of the actors in the issue networks has to show.

Despite the relatively high degrees, the scope of transnationalization is limited to countries and actors of the Global North. This suggests that the focus of the public debate within the studied countries is primarily on those causing the problem, rather than on those affected by it. This is true for both hyperlinks and referential links and is highly problematic, as it prevents the actors of the Global South from speaking for themselves in the national discourses of the Global North. As with other issues and media (Rogers \& Ben-David, 2008; Shumate \& Dewitt, 2008; Yang, 2012), the Web seems not to eliminate the north-south divide but to deepen it.

Furthermore, as the results have shown, language regions limit the scope of transnational communicative links. Links from non-English-speaking countries to Englishspeaking ones - especially the US - occur more often than vice versa. However, this pattern is not climate change-specific and has been documented by other studies looking at hyperlink networks (Barnett, Chon \& Rosen, 2001; Barnett et al., 2011; Halvais, 2000; Takhteyev, Gruzd \& Wellman, 2012). The same is true for the fact that actors from smaller countries link to actors from bigger countries more often than the other way round (e.g., Switzerland to Germany or the UK to the US). The issue networks analyzed here also reflect a pattern known from legacy media, where the US typically receives the most attention of any other country in other nations' media (Chang et al., 2009; Himelboim, 2010; Segev, 2010; Segev \& Hills, 2014). In return, the degree of transnationalization in the discourse on climate change in American mass media has been identified as comparatively low (Broadbent et al., 2016; Schäfer et al., 2018). This matches our results, according to which the US is the only country 
with a negative E-I ratio, indicating a stronger internal than external orientation of the actors in the issue network.

Overall, the Web's capability to integrate the complex spatiality of climate change into national discourses has proven to be limited. Regarding an inclusive and ambitious global climate policy that aims to meet the targets of the UNFCCC, not only the absence of actors from the global South seems problematic, but also the high visibility of US actors in the European discourses. In the US, climate change is a highly controversial issue (Dunlap et al., 2016), which is reflected in a strong online presence of domestic climate skeptics (Elgin, 2015; Schmid-Petri, 2017). In this polarized context, both skeptics and advocates find political allies. Transnational links are therefore less important for US actors (Häussler et al., 2017). The situation is different in Europe, where climate change skeptics constitute a counter-movement in most countries. As politically isolated actors, they use the Web to form transnational advocacy networks with like-minded actors from other countries. Recent research has shown that skeptics from Germany and the UK link to US skeptics for this purpose (Adam et al., 2019). Such an integration of skeptical actors into the national discourses of European countries may have a negative impact on the public support of constructive policies in these countries. In order to investigate this hypothesis, future research should not only unravel the linking behavior of the different camps (i.e., skeptics and advocates), but also show how they influence others — like citizens or the mass media — with their online communication behavior.

Moreover, future work should seek explanations for the reported patterns of national (non-)transnationalization. Besides country-specific factors, such as language and size, future studies should also take actor-specific factors, such as their position regarding climate change, into account. Such analyses would not only allow for a statement about which actors 
transnationalize the national discourses but also provide information about their possible intentions. Further studies may also conduct a combined analysis of network and content data (as in Schmid-Petri et al., 2018), as content provides context information for an accurate interpretation of communicative links (cf. De Maeyer, 2012). Missing context is a major limitation of the approach adopted here. In particular, it is not clear for referential links whether the actors are mentioned as speakers or addressees (cf. Koopmans \& Erbe, 2004), nor whether the links are meant to be critical or supportive. Another limitation of this study relates to the number of languages considered. Although German and English are the languages spoken in the studied countries, national issue networks do not have to be monolingual. This holds true for multilingual Switzerland but also for many other countries. Future studies should, therefore, consider more languages, both for the selection of countries and for the indexing of webpages. In addition, more national discourses on climate change should be examined. It would be particularly desirable that the integrative performance of issue networks in the Global South is examined.

Finally, the findings have shown that although hyperlinks and referential links are both communicative links, their use patterns differ. The horizon is wider with referential links, yet at the same time, they are used for more vertical-transnational references, as well as nonspecific references, than hyperlinks. Moreover, referential links are much more common than hyperlinks. This suggests that hyperlinks are used more selectively. They are a communicative tool that allows actors to make the Web content of others directly accessible to their readers (Park, 2003). This is neither always possible nor desired. For example, skeptics and advocates avoid linking to each other (Schmid-Petri et al., 2018). Referential links are less problematic in this respect: they do not make the content of the addressee directly accessible. They are also less language-sensitive and allow general references (e.g., to "the people"), as our results 
have shown. The analysis of hyperlinks therefore reveals not the complete picture. This should be taken into account when communicative links are used to study social and political processes. 


\section{References}

Adam, S. (2007). Symbolische Netzwerke in Europa: Der Einfluss der nationalen Ebene auf europäische Öffentlichkeit. Deutschland und Frankreich im Vergleich. Köln: Herbert von Halem.

Adam, S., Häussler, T., Schmid-Petri, H., \& Reber, U. (2019). Coalitions and countercoalitions in online contestation: An analysis of the German and British climate change debate. New Media \& Society, 21(11-12), 2671-2690.

doi:10.1177/1461444819855966

Adam, S., Häussler, T., Schmid-Petri, H. \& Reber, U. (2016). Identifying and analyzing hyperlink issue networks. In G. Vowe \& P. Henn (Eds.), Political communication in the online world: Theoretical approaches and research designs. New York: Routledge.

Paris Agreement (2015, December). 21st Conference of the Parties of the United Nations Framework on Climate Change in Paris, France (COP21). Retrieved from https://unfccc.int/sites/default/files/english_paris_agreement.pdf

Barnett, G. A., Chon, B.-S. \& Rosen, D. (2001). The structure of the internet flows in cyberspace. Networks and Communication Studies, 15(1-2), 61-80.

Barnett, G. A., Chung, C. J. \& Park, H. W. (2011). Uncovering transnational hyperlink patterns and web-mediated contents: A new approach based on cracking.com domain. Social Science Computer Review, 29(3), 369-384. doi:10.1177/0894439310382519

Barnett, G. A. \& Park, H. W. (2005). The structure of international internet hyperlinks and bilateral bandwidth. Annales des telecommunications, 60(9-10), 1110-1127. doi:10.1007/BF03219838

Benkler, Y. (2006). The wealth of networks: How social production transforms markets and freedom. New Haven: Yale University Press. 
Bennett, W. L., Lang, S. \& Segerberg, A. (2015). European issue publics online: The cases of climate change and fair trade. In T. Risse (Ed.), European public spheres: Politics is back. Cambridge: Cambridge University Press.

Brin, S. \& Page, L. (1998). The anatomy of a large-scale hypertextual Web search engine. Presented at the Seventh International World-Wide Web Conference (WWW 1998). Retrieved from http://ilpubs.stanford.edu:8090/361/

Broadbent, J. et al. (2016). Conflicting climate change frames in a global field of media discourse. Socius, 2, 1-17. doi:10.1177/2378023116670660

Burck, J., Hagen, U., Marten, F., Höhne, N. \& Bals, C. (2019). Climate change performance index: results 2019. Bonn: Germanwatch, Climate Action Network International and NewClimate Institute., Retrieved from https://www.climate-change-performanceindex.org/the-climate-change-performance-index-2019

Cammaerts, B. \& Van Audenhove, L. (2005). Online political debate, unbound citizenship, and the problematic nature of a transnational public sphere. Political Communication, 22(2), 179-196. doi:10.1080/10584600590933188

Chang, T.-K., Himelboim, I. \& Dong, D. (2009). Open global networks, closed international flows. International Communiction Gazette, 71(3), 137-159. doi:10.1177/1748048508100910

De Maeyer, J. (2012). Towards a hyperlinked society: A critical review of link studies. New Media \& Society, 15(5), 737-751. doi:10.1177/1461444812462851

Deutsch, K. (1953). Nationalism and social communication: An inquiry into the foundations of nationality. Cambridge: University Press.

Di Gregorio, M., Fatorelli, L., Paavola, J., Locatelli, B., Pramova, E., Nurrochmat, D. R., May, P. H., Brockhaus, M., Sari, I. M. \& Kusumadewi, S. D. (2019). Multi-level 
governance and power in climate change policy networks. Global Environmental Change, 54, 64 - 77. doi:10.1016/j.gloenvcha.2018.10.003

Dunlap, R. E., McCright, A. M. \& Yarosh, J. H. (2016). The political divide on climate change: Partisan polarization widens in the U.S.. Environment: Science and Policy for Sustainable Development, 58(5), 4-23. doi:10.1080/00139157.2016.1208995

Eide, E. \& Kunelius, R. (2010). Domesticating global moments: A transnational study on the coverage of the Bali and Copenhagen climate summits. In E. Eide \& R. Kunelius (Eds.), Global climate-local journalisms: A transnational study of how media make sense of climate summits. Bochum: Projektverlag.

Elgin, D. J. (2015). Utilizing hyperlink network analysis to examine climate change supporters and opponents. Review of Policy Research, 32(2), 226-245. doi:10.1111/ropr.12118

Esser, F. \& Hanitzsch, T. (2012). On the why and how of comparative inquiry in communication studies. In F. Esser \& Hanitzsch (Eds.), Handbook of comparative communication research. London: Routledge.

Finkel, J. R., Grenage, T. \& Manning, C. (2005). Incorporating non-local information into information extraction systems by Gibbs samplings. In Proceedings of the 43nd Annual Meeting of the Association for Computational Linguistics (ACL 2005) (p. 363370). Retrieved from https://nlp.stanford.edu/ manning/papers/gibbscrf3.pdf

Fraser, N. (2007). Transnationalizing the public sphere: On the legitimacy and efficacy of public opinion in a post-Westphalian world. Theory, Culture \& Society, 24(4), 7-30.

Friedland, L. A. \& Rojas, H. (2006). The networked public sphere. Javnost - The Public, 13(4), 5-26. doi:10.1080/13183222.2006.11008922 
Gerhards, J. \& Rössel, J. (1999). Zur Transnationalisierung der Gesellschaft der Bundesrepublik: Entwicklungen, Ursachen und mögliche Folgen für die europäische Integration. Zeitschrift für Soziologie, 25(5), 325-344.

Gerhards, J. \& Schäfer, M. S. (2010). It the internet a better public sphere? Comparing old and new media in the USA and Germany. New Media \& Society, 12(1), 143-160. doi:10.1177/1461444809341444

González-Bailón, S. (2009). Opening the black box of link formation: Social factors underlying the structure of the Web. Social Networks, 31(4), 271-280. doi:10.1016/j.socnet.2009.07.003

Halvais, A. (2000). National borders on the World Wide Web. New Media \& Society, 2(1), 728. doi:10.1177/14614440022225689

Häussler, T., Adam, S., Schmid-Petri, H., \& Reber, U. (2017). How political conflict shapes online spaces. A comparison of climate change hyperlink networks in the U.S. and Germany. International Journal of Communication 11, 3096-3117. Retrieved from https://ijoc.org/index.php/ijoc/article/view/5644

Häussler, T., Schmid-Petri, H., Adam, S., Reber, U., \& Arlt, D. (2016). The climate of debate: How institutional factors shape legislative discourses on climate change. Studies in Communication Sciences 16, 94-102. doi:10.1016/j.scoms.2016.04.002

Heft, A., Mayerhöffer, E., Reinhardt, S., \& Knüpfer, C. (2019). Beyond Breitbart: Comparing right-wing digital news infrastructures in six western democracies. Policy \& Internet, 12(1), doi:10.1002/poi3.219

Hepp, A., Elsler, M., Lingenberg, S., Mollen, A., Möller, J. \& Offerhaus, A. (2016). The communicative construction of Europe: Cultures of political discourse, public sphere 
and the Euro crisis. Houndmills, Basingstoke: Palgrave Macmillan. doi:10.1057/9781137453136

Himelboim, I. (2010). The international network structure of news media: An analysis of hyperlinks usage in news Web sites. Journal of Broadcasting \& Electronic Media, 54(3), 373-390. doi:10.1080/08838151.2010.499050

Iacobuta, G., Dubash, N. K., Upadhyaya, P., Deribe, M. \& Höhne, N. (2018). National climate chnage mitigation legislation, strategy and targets: A global update. Climate Policy, 18(9), 1114-1132. doi:10.1080/14693062.2018.1489772

IPCC (2014). Climate change 2014: Synthesis report. Contribution of working groups I, II and III to the fifth assessment report of the Intergovernmental Panel on Climate Change. Genève: IPCC. Retrieved from http://ar5-syr.ipcc.ch/

Janc, K. (2015). Geography of hyperlinks: Spatial dimensions of local government websites. European Planning Studies, 23(5), 1019-1037. doi:10.1080/09654313.2014.889090

Jänicke, M. (2017). The multi-level system of global climate governance - the model and its current state. Environmental Policy and Governance, 27(2), 108-121. doi:10.1002/eet.1747

Jordan, A., van Asselt, H., Berkhout, F., Huitema, D. \& Rayner, T. (2012). Understanding the paradoxes of multilevel governing: Climate change policy in the European Union. Global Environmental Politics, 12(2), 43-66. doi:10.1162/GLEP_a_00108

Koopmans, R. (2015). How advanced is the Europeanization of public spheres? Comparing German and European structures of political communication. In T. Risse (Ed.), European public spheres: Politics is back. Cambridge: Cambridge University Press. 
Koopmans, R. \& Erbe, J. (2004). Towards a European public sphere? Vertical and horizontal dimensions of Europeanized political communication. Innovation, 17(2), 97-118. doi:10.1080/1351161042000238643

Koopmans, R. \& Statham, P. (2010). Theoretical framework, research design, and methods. In R. Koopmans \& P. Statham (Eds.), The making of a European public sphere: Media discourse and political contention. Cambridge: Cambridge University Press.

Koopmans, R. \& Zimmermann, A. (2010). Transnational political communication on the internet: Search engine results and hyperlink networks. In R. Koopmans \& P. Statham (Eds.), The making of a European public sphere: Media discourse and political contention. Cambridge: Cambridge University Press.

Krackhardt, D. \& Stern, R. N. (1988). Informal networks and organizational crises: An experimental simulation. Social Psychology Quarterly, 51(2), 123-140.

Kriesi, H. (2004). Strategic political communication: Mobilizing public opinion in "audience democracies". In F. Esser \& B. Pfetsch (Eds.), Comparing political communication: Theories, cases, and challenges. Cambridge: Cambridge University Press.

Marres, N. (2006). Net-work is format work: Issue networks and the sites of civil society politics. In J. Dean, J. W. Anderson \& G. Lovik (Eds.), Reformatting politics: Information technology and global civil society. New York: Routledge.

Marres, N. (2015). Why map issues? On controversy analysis as a digital method. Sience, Technology, \& Human Values, 40(5), 655-686. doi:10.1177/0162243915574602

Marres, N. \& Rogers, R. (2005). Recipe for tracing the fate of issues and their publics on the Web. In B. Latour \& P. Weibel (Eds.), Making things public: Atmospheres of democracy. Karlsruhe, Cambridge: ZKM Center for Art and Media, The MIT Press. 
McCright, A. M., Dunlap, R. E. \& Marquart-Pyatt Sandra, T. (2015). Political ideology and views about climate change in the European Union. Environmental Politics, 25(2), 338-358. doi:10.1080/09644016.2015.1090371

Olausson, U. (2009). Global warming — global responsibility? Media frames of collective action and scientific certainty. Public Understanding of Science, 18, 421-436. doi:10.1177/0963662507081242

Painter, J. \& Gavin, N. (2016). Climate skepticism in British newspapers, 2007-2077. Environmental Communication, 10(4), 432-452. doi:10.1080/17524032.2014.995193

Park, H. W. (2003). Hyperlink network analysis: A new method for the study of social structure on the Web. Connections, 25(1), 49-61.

Park, H. W., Barnett, G. A. \& Chung, C. J. (2011). Structural changes in the 2003-2009 global hyperlink networks. Global Networks, 11(4), 522-542. doi:10.1111/j.14710374.2011.00336.x

Pfetsch, B., Adam, S. \&Bennett, W. L. (2013). The critical linkage between online and offline media - An approach to researching the conditions of issue spill-over. Javnost, 20(3):5-18. doi:10.1080/13183222.2013.11009118

Rogers, R. (2013). Mapping public Web space with the Issuecrawler. In B. Reber \& C. Brossaud (Eds.), Digital cognitive technologies: Epistemology and the knowledge economy. Hoboken: Wiley.

Rogers, R. \& Ben-David, A. (2008). The Palestinian-Israeli peace process and transnational issue networks: The complicated place of the Israeli NGO. New Media \& Society, 10(3), 497-528. doi:0.1177/1461444807085321 
Schäfer, M. S. (2012). Online communication on climate change and climate politics: A literature review. Wiley Interdisciplinary Reviews: Climate Change, 3(6), 527-543. doi:10.1002/wcc.191

Schäfer, M. S., Post, S., Schwab, R. \& Kleinen-von Königslöw, K. (2018).

Transnationalisierte Öffentlichkeit und Klimapolitik: Akteursensembles in der Medienberichterstattung von 15 Ländern. Publizistik, 63, 207-244. doi:10.1007/s11616-018-0420-6

Schmid-Petri, H. (2017). Politicization of science: how climate change skeptics use experts and scientific evidence in their online communication. Climatic Change, 145(3-4), 523-537. doi:10.1177/1748048518825092

Schmid-Petri, H., Adam Silke, Reber, U., Häussler, T., Maier, D., Miltner, P., Pfetsch, B. \& Waldherr, A. (2018). Homophily and prestige: An assessment of their relative strength to explain link formation in the online climate change debate. Social Networks, 55, 47 54. doi:10.1016/j.socnet.2018.05.001

Segerberg, A. (2012). Digital media and civil society networks: National and transnational publics. Statsvetenskaplig Tidskrift, 113(1), 115-124.

Segev, E. (2010). Mapping the international: Global and local salience and news-links between countries in popular news sites worldwide. International Journal of Internet Science, 5(1), 48-71. Retrieved from http://www.ijis.net/ijis5_1/ijis5_1_segev_pre.html

Segev, E. \& Hills, T. (2014). When news and memory come apart: A cross-national comparison of countries' mentions. International Communication Gazette, 76(1), 6785. doi: $10.1177 / 1748048513504159$ 
Shapiro, M. A. \& Park, H. W. (2015). More than entertainment: YouTube and public responses to the science of global warming and climate change. Social Science Information, 54(1), 115-145. doi:10.1177/0539018414554730

Shumate, M. \& Dewitt, L. (2008). The north/south divide in NGO hyperlink networks. Journal of Computer-Mediated Communication, 13, 405-428. doi:10.1111/j.1083$6101.2008 .00402 . x$

Simonis, G. (2017). Das Mehrebenensystem der Klimagovernance: Verflochtene Handlungsebenen. In G. Simonis (Ed.), Handbuch globale Klimapolitik. Leiden: Ferdinand Schöningh.

Stein, L. (2009). Social movement web use in theory and practice: A content analysis of US movement websites. New Media \& Society, 11(5), 749-771. doi:10.1177/1461444809105350

Takhteyev, Y., Gruzd, A. \& Wellman, B. (2012). Geography of Twitter networks. Social Networks, 34(1), 73-81.

United Nations Framework Convention on Climate Change (UNFCCC) (1992, May). United Nations Conference on Environment and Development (UNCED) in Rio de Janeiro. Retrieved from http://unfccc.int/files/essential_background/background_publications_htmlpdf/ application/pdf/conveng.pdf

Volkmer, I. (2019). The transnationalization of public spheres and global policy. In D. Stone \& K. Moloney (Eds.), The Oxford handbook of global policy and transnational administration. Oxford: Oxford University Press. 
Waldherr, A., Maier, D., Miltner, P. \& Günther, E. (2017). Big data, big noise: The challenge of finding issue networks on the web. Social Science Computer Review, 35(4), 427443. doi: $10.1177 / 0894439316643050$

Wessler, H., Peters, B., Brüggemann, M., Kleinen-von Königslöw, K. \& Sifft, S. (2008). Transnationalization of public spheres. Basingstoke: Palgrace Macmillan.

Wessler, H., Wozniak, A., Hofer, L. \& Lück, J. (2016). Global multimodal news frames on climate change: A comparison of five democracies around the world. The International Journal of Press/Politics, 21(4), 423-445. doi:0.1177/1940161216661848

Yang, A. (2012). When transnational civil network meets local context: An exploratory hyperlink network analysis of northern/southern NGOs' virtual network in China. Journal of International and Intercultural Communication, 5(3), 40-60. doi:10.1080/17513057.2012.719632

Zimmermann, A. C. (2006). Demokratisierung und Europäisierung online? Massenmediale politische Öffentlichkeit im Internet (Doctoral Dissertation). Retrieved from http://www.diss.fu-berlin.de/diss/receive/FUDISS_thesis_000000003532 


\section{Appendix I}

\begin{tabular}{|c|c|c|}
\hline \multicolumn{3}{|l|}{ Germany } \\
\hline \multirow{4}{*}{ Advocates } & Heinrich Boell Stiftung & http://klima-der-gerechtigkeit.boellblog.org \\
\hline & Greenpeace Germany & http://www.greenpeace.de/themen/klima/nachrichten \\
\hline & Potsdam Institute for Climate Impact Research & http://www.pik-potsdam.de/aktuelles?set_language $=\mathrm{de}$ \\
\hline & WWF Germany & http://www.wwf.de/themen-projekte/klima-energie \\
\hline \multirow{4}{*}{ Skeptics } & Analyse + Aktion & http://astrologieklassisch.wordpress.com/tag/klimawandel \\
\hline & EIKE - Europäisches Institut für Klima und Energie & http://www.eike-klima-energie.eu \\
\hline & Klimaüberraschung & http://www.klima-ueberraschung.de \\
\hline & Klimaskeptiker & http://www.klimaskeptiker.info \\
\hline \multicolumn{3}{|c|}{ Switzerland } \\
\hline \multirow{4}{*}{ Advocates } & WWF Switzerland & http://www.wwf.ch/de/hintergrundwissen/klima/ \\
\hline & Alliance Sud & http://www.alliancesud.ch/de/cs \\
\hline & ETH Zurich Klimablog & http://blogs.ethz.ch/klimablog/ \\
\hline & Klimainitiative & http://www.klimainitiativeja.ch/ \\
\hline \multirow{4}{*}{ Skeptics } & Bilderberger & http://www.bilderberger.ch/?cat=1686 \\
\hline & Arlesheim reloaded & http://arlesheimreloaded.ch/category/klimawandel/ \\
\hline & We are change & http://www.wearechange.ch/hintergrund/umwelt-und-klima \\
\hline & Klimaschwindel & http://www.klima-schwindel.com \\
\hline \multicolumn{3}{|c|}{ United Kingdom } \\
\hline \multirow{4}{*}{ Advocates } & Greenpeace UK & http://www.greenpeace.org.uk/climate \\
\hline & Oxfam UK & $\begin{array}{l}\text { http://www.oxfam.org.uk/what-we-do/issues-we-work-on/ } \\
\text { climate-change }\end{array}$ \\
\hline & Friends of the Earth UK & http://www.foe.org/projects/climate-and-energy \\
\hline & WWF UK & $\begin{array}{l}\text { http://www.wwf.org.uk/what_we_do/ } \\
\text { tackling_climate_change }\end{array}$ \\
\hline \multirow{4}{*}{ Skeptics } & The Global Warming Policy Foundation & http://thegwpf.org \\
\hline & Global Warming Hysteria & http://www.globalwarminghysteria.com/ \\
\hline & Climate Resistance & http://www.climate-resistance.org/ \\
\hline & Repealtheact & http://repealtheact.org.uk/ \\
\hline \multicolumn{3}{|c|}{ United States } \\
\hline \multirow{4}{*}{ Advocates } & Climate Central & http://www.climatecentral.org \\
\hline & Greenpeace USA & $\begin{array}{l}\text { http://www.greenpeace.org/usa/en/campaigns/global- } \\
\text { warming-and-energy }\end{array}$ \\
\hline & Worldwatch Institute & http://www.worldwatch.org/climate-energy \\
\hline & WWF U.S. & http://www.worldwildlife.org/climate/index.html \\
\hline \multirow{4}{*}{ Skeptics } & The Heartland Institute & http://heartland.org/issues/environment \\
\hline & Climate Depot & http://www.climatedepot.com \\
\hline & C3 Headlines & http://www.c3headlines.com \\
\hline & Watts Up With That? & http://wattsupwiththat.com \\
\hline
\end{tabular}

Table 2: Starting points for the snowball-sampling of websites in Germany, Switzerland, the United Kingdom, and the United States. 